\title{
Multi-Criteria Approach for Selecting Optimal Dozer Type in Open-Cast Coal Mining
}

\author{
Ivan Jankovic ${ }^{1}$, Stevan Djenadic ${ }^{2}$, Dragan Ignjatovic ${ }^{2}$, Predrag Jovancic ${ }^{2}$, \\ Tomislav Subaranovic ${ }^{2}$ and Ivica Ristovic ${ }^{2, *}$ \\ 1 Ministry of Mining and Energy, 11000 Belgrade, Serbia; ivan.jankovic@mre.gov.rs \\ 2 Faculty of Mining and Geology, University of Belgrade, 11000 Belgrade, Serbia; \\ stevan.djenadic@rgf.bg.ac.rs (S.D.); dragan.ignjatovic@rgf.bg.ac.rs (D.I.); \\ predrag.jovancic@rgf.bg.ac.rs (P.J.); tomislav.subaranovic@rgf.bg.ac.rs (T.S.) \\ * Correspondence: ivica.ristovic@rgf.bg.ac.rs; Tel.: +381-11-3241-121
}

Received: 15 March 2019; Accepted: 29 May 2019; Published: 12 June 2019

\begin{abstract}
In a continuous system of production in open-cast coal mining, in addition to the basic machinery which consists of highly productive machines (bucket-wheel excavators, bucket-chain excavators, spreaders, conveyor-belt transporters, etc.) that provide an uninterrupted exploitation of mineral ores, the usage of auxiliary machinery is also necessary. The auxiliary machinery provides the possibility of using the capacities of basic machinery adequately and timely. Further, it must be mentioned that the auxiliary machinery generates up to $20 \%$ of the total mining expenses. Dozers are the most commonly used machines. Choosing the adequate dozer of the right type and manufacturer is of great importance and can be made easier by carrying out an analysis of the existent operational-exploitative parameters. In this paper, the method of grading the operational-exploitative parameters of dozer is defined. The choice of the optimal type of dozer was conducted by using the analytical hierarchy process (AHP).
\end{abstract}

Keywords: analytical hierarchy process (AHP); dozers; coal mining; open-cast mining

\section{Introduction}

The process of ore exploitation in open-cast coal mining is complex and demands hiring many people and providing varied equipment. In order to provide continuous (twenty-four hours a day) production and to excavate the planned amount of ore and overburden in an open-cast coal mine, it is necessary to achieve optimal working conditions. The operational efficiency of the basic (continuous) machinery is in a direct correlation with the work of the auxiliary (discontinuous) machinery, whose role is to accomplish all of the auxiliary workings on time. In effect, in the process of production in an open-cast coal mine, there must always be several different auxiliary machines available. The absence or insufficient number of the adequate auxiliary machinery leads towards an inadequate carrying out of the auxiliary workings, which further hinders the working of the basic machinery, lowers the production and may lead to breakdowns or endanger the people. In open-cast coal mines, dozers often work under aggravated conditions with the materials of different physical-mechanical qualities and under variable weather conditions. Under such circumstances the workload on the equipment significantly oscillates, making room for frequent changes of the direction, course and the speed of movement. For these reasons, the evaluation of the functioning of this type of machines is done with the aim of showing the elementary parameters influencing their current work and predicting any future events by analysing those parameters and their mutual interaction. The method of evaluation is supposed to show the connection between the characteristics of the machines and the exact working conditions in the open-cast coal mine, leading to the right choice of machine in relation to those conditions. 
Acquiring new mining machines presents a huge investment whether it is a small or a big company. In addition, sometimes the policy of the company is such that it does not allow for purchasing the machines from exclusively one manufacturer. That is why the decision about the purchase of the machines should be right and unbiased, so as to avoid any unwanted future loses [1]. The decision about the purchase can be made in a few different ways, and it is certainly the most reliable if it is made after an adequate data analysis with the support of the appropriate mathematical models and software [2]. Multiple-criteria methods that are widely used in different areas include: Analytical hierarchy process (AHP) [3], Preference Ranking Organization Method for Enrichment and Evaluations (PROMOTHEE) [4], ELimination and Choice Expressing REality (ELECTRE) [5], Technique for Order of Preference by Similarity to Ideal Solution (TOPSIS) [6], Fuzzy logic (FUZZY) [7], Multiple-criteria Optimization and the Compromise Solution (VIKOR) [8].

In this paper, in order to define optimal evaluating methodology, the AHP method was chosen as the most suitable due to the possibility of a total and partial analysis of every parameter. The defined methodology, in relation to which the evaluation of the machine is conducted, consists of four basic criteria and fourteen sub-criteria. The technical, economic, exploitation and survey parameters are the four most important criteria considered in the analysis [9-12].

In order to define the evaluation model, it is necessary to analyse the working machines from different manufacturers but of the same class and under the approximately same conditions. In the paper, the analysed data were taken from the Kolubara mining basin (Serbia) in which dozers of different manufacturers are in operation. The total number of analysed dozers in this paper was $55,70 \%$ of the same class dozers working in the Kolubara mining basin. The analysis covered four different machine manufacturers, and to provide the necessary objectivity in the interpretation of the results of the analysis, the prefix Type (T1, T2, T3, T4) will be used instead of the names of the manufacturers.

\section{Materials and Method}

\subsection{The Usage of the Dozers in Open-Cast Mining}

Dozers are tractors equipped with a front pusher blade, which can be raised or lowered by hydraulic control and is used for digging and pushing. The main role of dozers in open-cast coal mines is to dig soil and transport it to the dumping point [13]. However, they are also used to clear routes for the transportation of excavators and spreaders, road cuts, ramping down, levelling ground on the terrain, the movement of the transporters, breaking piles, pushing scattered masses into the zone of effect of the bucket-wheel excavator, shaping slopes, cleaning the benches, pulling operating stations or other machines, checking the ground stability, etc. The classification of the auxiliary workings which are done using the dozer in the big open-cast coal mines is shown schematically in Figure 1 [14].

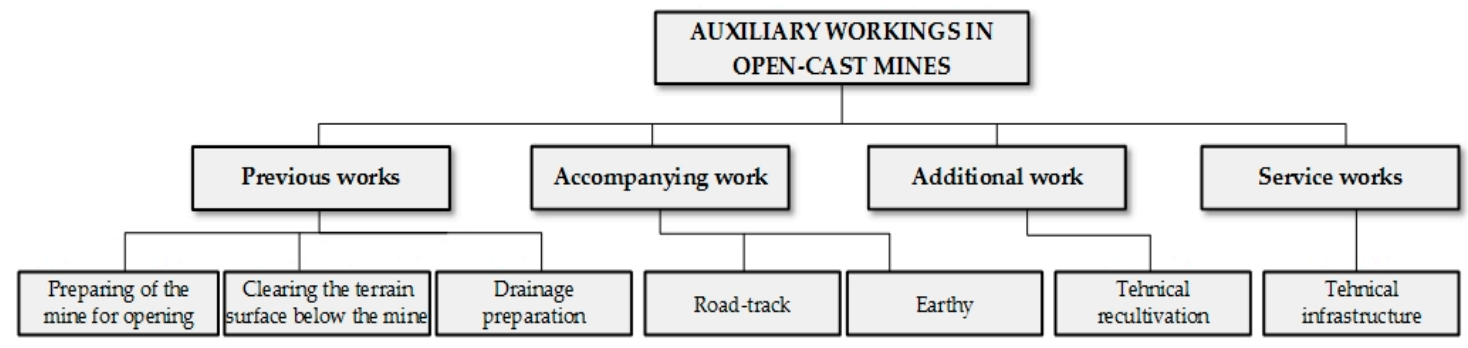

Figure 1. Auxiliary working classification.

They are classified according to different criteria, most commonly according to [15]:

- towing capacity (very heavy, heavy, of medium weight, light and very light),

- the strength of the machine (very strong, strong, medium strength, low strength, and very low strength),

- the type of the transportation mechanism (caterpillar, pneumatic), 
- the position of the working organ (bulldozers, angle-dozers, tilt-dozers).

The dozers are designed and built to satisfy the highest standards when working in a three-shift mode, even under the aggravated conditions, unstable weather conditions, such as high or low temperature or high humidity.

The analysed dozers in the Kolubara coal mining basin (Serbia), according to the strength of the machine, fell into the class of strong dozers, and the information on the manufacturer, type and number are stated in Table 1. During further analysis, on the basis of the quality of the available information, Liebherr PR-752/754, Caterpillar D8R, Dressta TD25M, Shantui SD32W dozers were taken into consideration.

Table 1. Dozers in the Kolubara mining basin (January 2018).

\begin{tabular}{cccc}
\hline Manufacturer & Label & Number & $\mathbf{\%}$ \\
\hline Liebherr & PR-752/754 & 3 & 3.85 \\
Caterpillar & D8R & 15 & 19.23 \\
Dressta & TD25M & 14 & 17.95 \\
Shantui & SD32W & 23 & 29.49 \\
& Other & 23 & 29.48 \\
& Total: & 78 & 100 \\
\hline
\end{tabular}

\section{2. $A H P$}

AHP, which was used in the paper, represents the most commonly used mathematical method and is based on a multiple-criteria approach in the analysis of the existing data. AHP was designed by Tomas L. Saaty [16], and it can be used in numerous fields, such as medicine [17], agriculture [18], economics [19], engineering [20], traffic [21], etc. The AHP method finds its role in the field of mining as well [10,22-27].

The main advantage of this method is ease of use, followed by the quality of output data. It relies on the theory of the relative weight determination of the factors in decision-making. It is based on the measurements made by comparing pairs of data, and it depends on the evaluation of experts for defining priority scales [28]. Firstly, in order to make the right decision, it is necessary to define the problem, the purpose of making the decision, the criteria and sub-criteria for the evaluation of alternatives, alternative activities that should be carried out, and the interest of the party to which the decision applies [29]. A great advantage of the AHP method is its ability to identify and analyse the inconsistency of the decision-maker in the process of deciding on the priorities in the hierarchal structure.

The general schematic display of the AHP method structure is shown in Figure 2. The goal (zero level) of the AHP method structure is at the very top. After the goal, level 1 containing the criteria, after which come the sub-criteria. The last level of the structure (level 2) contains the alternative choices which are analysed according to the defined criteria and sub-criteria. The number of criteria and sub-criteria in the model is unlimited. On the basis of the defined criteria and sub-criteria the dependency between them and the qualities of the considered alternatives is established, they are evaluated in comparison, after which we get the final solution in the form of the best choice [10].

Basically, the method represents a relative measurement, because the subject of interest is not the exact measurements of separate quantities but the proportional relationship that exists among them. It is based on three main principles [30]: Identity and decomposition, the comparison of pairs, and the synthesis of priorities. 


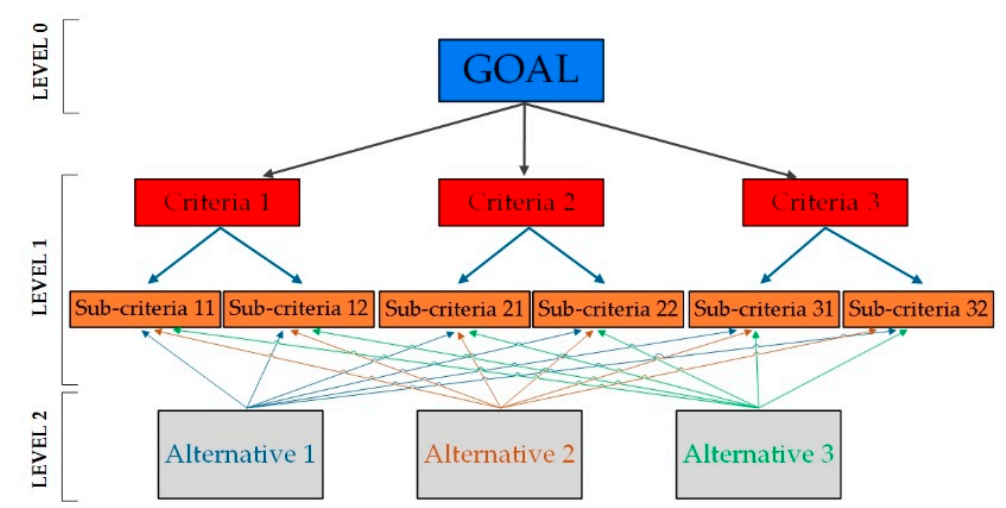

Figure 2. The schematic display of the structure of the analytical hierarchy process (AHP) method.

The mathematical basis of the AHP method consists of four steps:

1. Production of a hierarchical model, that is, the structure of the decision-making problem (presented in Figure 2);

2. The use of an appropriate Saaty scale of the relative importance in reciprocal comparison of the elements of the structure in pairs (Figure 3 and Table 2);

3. The calculation of the individual priorities of the criteria weight, sub-criteria and alternatives weights, which are afterwards combined into the total priority alternatives;

4. Checking the consistency of the decision-maker.

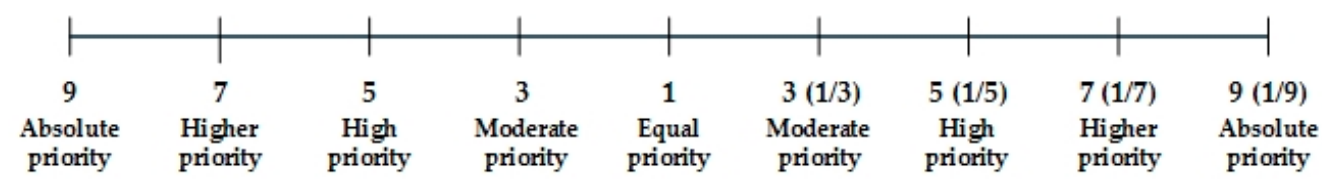

Figure 3. An example of a Saaty scale for defining priorities.

Table 2. AHP scale of importance.

\begin{tabular}{lcc}
\hline \multicolumn{1}{c}{ The Level of Importance } & Numerical Value & Reciprocal Value \\
\hline Absolute priority & 9 & $1 / 9(0.111)$ \\
Higher to absolute priority & 8 & $1 / 8(0.125)$ \\
Higher priority & 7 & $1 / 7(0.143)$ \\
High to higher priority & 6 & $1 / 6(0.167)$ \\
High priority & 5 & $1 / 5(0.200)$ \\
Moderate to high priority & 4 & $1 / 4(0.250)$ \\
Moderate priority & 3 & $1 / 3(0.333)$ \\
Equal to moderate priority & 2 & $1 / 2(0.500)$ \\
Equal priority & 1 & $1(1.000)$ \\
\hline
\end{tabular}

The initial assumption in this work is that the simplest and the most correct decisions are made when there are only two alternatives available in one interaction. The main principle of the AHP method is that a complex problem should be broken down into its elementary components which are then compared in pairs. Every component of the hierarchical model is compared in pairs using the Saaty scale of relative importance which is presented in Figure 3.

Table 2 shows the values of the priorities in comparison of the elements. 
The result of elements pair-wise comparison is the numerical value that presents priority vector (W). Calculating the priority vector of each element of the analysis by equation number 1 creates the possibility of forming the mathematical matrix M (by Equation (2)).

$$
\begin{gathered}
W=\sum_{j=1}^{n} \frac{W_{i}}{W_{j}}=W_{i}\left(\sum_{j=1}^{n} \frac{1}{W_{j}}\right) i=1, \ldots, n \\
M=\left[\begin{array}{cccc}
w_{1} / w_{1} & w_{1} / w_{2} & \ldots & w_{1} / w_{n} \\
w_{1} / w_{1} & w_{2} / w_{2} & \ldots & w_{2} / w_{n} \\
\ldots & \ldots & \ldots & \ldots \\
w_{n} / w_{1} & w_{n} / w_{2} & \ldots & w_{n} / w_{n}
\end{array}\right]=\left[\begin{array}{cccc}
a_{11} & a_{12} & \ldots & a_{1 n} \\
a_{21} & a_{22} & \ldots & a_{2 n} \\
\ldots & \ldots & \ldots & \ldots \\
a_{n} & a_{n 2} & \ldots & a_{n n}
\end{array}\right]
\end{gathered}
$$

The fourth and final step in the AHP method is checking for mistakes [24], that is, checking of the consistency of the decision-maker. The mathematical check of the Consistency Index (CI) is done using Equation (3).

$$
\mathrm{CI}=\frac{\left(\lambda_{\max }-\mathrm{n}\right)}{(\mathrm{n}-1)}
$$

where $\lambda_{\max }$ represents the maximum value of the calculated matrix and is defined using Equation (4) while $\mathrm{n}$ is the number of analysed objects.

$$
\lambda_{\max }=\frac{1}{n} \sum_{i=1}^{n} \lambda_{i}
$$

The Consistency Ratio (CR) is defined using the following equation:

$$
\mathrm{CR}=\frac{\mathrm{CI}}{\mathrm{RI}}
$$

where RI is the Random Consistency Index (Table 3) which depends on the number of analysed objects $n$.

Table 3. The values of the Random Consistency Index (RI) (Saaty, 1991).

\begin{tabular}{ccccccccccc}
\hline $\mathbf{n}$ & $\mathbf{1}$ & $\mathbf{2}$ & $\mathbf{3}$ & $\mathbf{4}$ & $\mathbf{5}$ & $\mathbf{6}$ & $\mathbf{7}$ & $\mathbf{8}$ & $\mathbf{9}$ & $\mathbf{1 0}$ \\
\hline $\mathrm{RI}$ & 0.00 & 0.00 & 0.52 & 0.89 & 1.11 & 1.25 & 1.35 & 1.40 & 1.45 & 1.49 \\
\hline
\end{tabular}

In order for the method to be correct one condition must be fulfilled. The result of the calculated value of the Consistency Ratio when it comes to consistency must be lower than 0.1 (less than 10\%).

In Figure 4, the diagram of the order of the AHP method in choosing the right dozer is presented, from the initial phase of defining the goal to its fulfillment [31]. 


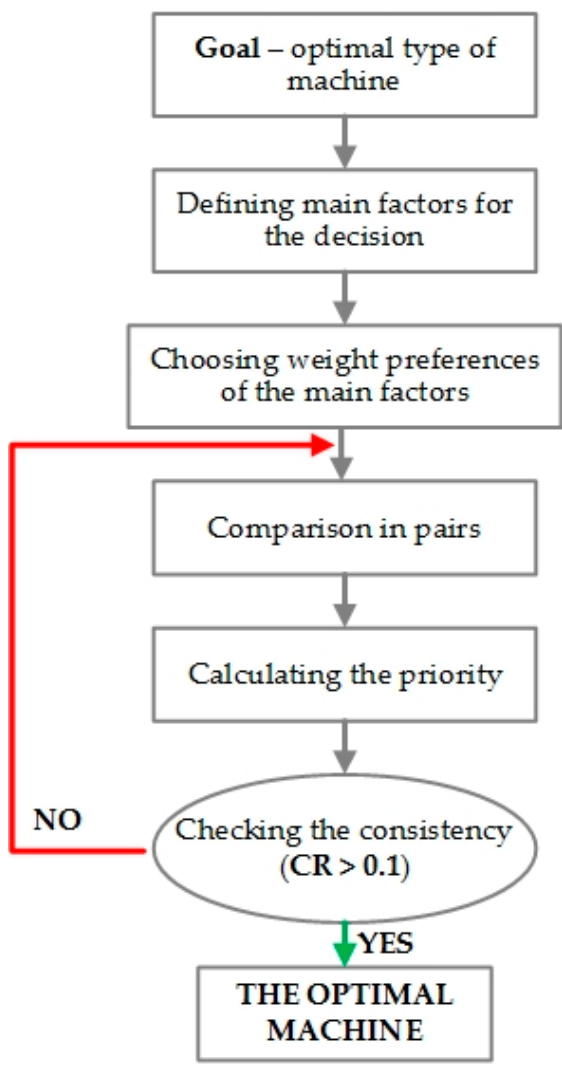

Figure 4. The stages in the decision-making process in choosing the optimal type of machine by applying the AHP method.

\section{Results}

The functioning of a dozer can be defined based on four basic criteria:

- Technical parameters;

- Economic parameters;

- Exploitation parameters;

- Survey parameters.

\subsection{Tehnical Parameters (TP)}

As far as the first criterion is concerned, the technical parameters of the considered equipment characterize the performance of the machine defined by the manufacturers of the equipment. Those were actually parameters which characterized the possibilities of the functioning of the machine under both nominal and aggravated working conditions. The sub-criteria of the technical parameters which were analysed were: Engine power, towing force, transmission type, and undercarriage type.

Taking into account the engine power (EP), the analysed dozers belonged to the group of strong dozers in the range of the 190-300 kW class, and according to the nominal towing force (TF) to the group of heavy dozers $250-350 \mathrm{kN}$. In order to evaluate the priority, the range of the class for both sub-criteria was divided into 10 equal parts, and each alternative defined its priority in relation to that division.

According to transmission type (TT), there are two types of dozers: Those with hydrodynamic and those with hydrostatic systems. Greater priority was assigned to hydrostatic systems (equal to moderate priority on Saaty scale), because of the possibility of achieving a stronger transmission connection, independence regarding position and power supply, as well as automatic protection against overcharging [32]. 
The dozers which are used in open-cast mines are dozers that have a caterpillar transport system. The pneumatic transport system is used in the construction industry. The analysis of the undercarriage type (UT) implies that the dozers in question were caterpillar transport system dozers. They were divided into two groups: Dozers with the triangular type and dozers with the flat type. Priority was given to the triangular type (equal to moderate priority on Saaty scale) because of better balance, greater traction, allowing for a greater percentage of the conversion of power into towing force, etc.

\subsection{Economic Parameters (EcP)}

The second criterion - the economic parameters—is the best indicator of the successful functioning of the entire open-cast mine, as well as the exploitation of the equipment and machines used there. The sub-criteria implemented into the economic parameters were: Ownership costs, operational costs, and human resource costs [33].

When estimating the ownership costs (OW), the necessary information was the delivery price of the machine, while for the amortization period a period of 10 years was assumed. For machines which are not used very often, the coefficient of amortization which is in accordance with the way in which the machine has been used so far was adopted.

The operational costs (OP) included the cost of fuel, lubricants and oils, maintenance and the cost of hiring the maintenance staff.

The human resource costs (HR) were identified as the amount of costs of hiring machine operators. To calculate the costs, the necessary information was: Shift duration, gross salary, as well as the reserve coefficient (1.25) in the worker-machine relation.

\subsection{Exploitation Parameters (ExP)}

The third criterion-the exploitation parameters-shows the current condition of the machines, the history of their work, as well as the trends concerning the maintenance of the machines and the amount of activity during work. The most significant parameters which have been the most influential in the analysis of the prior functioning of the machines were: Average of machine-hours per ten years, work until a general repair, average number of failures per thousand working hours of machine, and technical availability.

The evaluation of the average working hours $(\mathrm{WH})$ was analysed by observing each machine individually during the first ten years it spent in exploitation. For each type of machine the average machine-hours were separately calculated for each year. Using the given data, the mean value of machine-hours per year for every type of machine was calculated. That data represents a valuable source of information about the possible expectations regarding the ability of the machine on an annual level, while showing the exact degree of the machine usage by the owner.

The parameter work until a general repair (GR) was also an important indicator of the expected functioning of the machine. Based on the data about the previous work of the machine of the same type under similar or exact conditions, it can be predicted how the machine will function in the future period. By analysing the machines of the dozer type, it was concluded that a general repair is necessary after six years of usage.

Based on the data of the number of interventions and the achieved working hours of machine, it was possible to determine the average failures (AF). This information was the best indicator of the intensity of breakdowns for each of the possible alternative choices.

Technical availability (TA) is a characteristic which describes and evaluates the work and maintenance of a realistic system. In theory, availability represents the probability of a technical system being able to work at any given time $t$, or being able to join in on the work, and of being able to carry out the given task to a satisfactory level at the same time [34]. The input parameters for calculating the availability of the technical systems (in this case what they are like for dozers) were: the time of work done $-\mathrm{T}_{\mathrm{op}}$, the time of the planned standstill $-\mathrm{T}_{\mathrm{ps}}$, the time of unplanned standstill $-\mathrm{T}_{\mathrm{ns}}$. On the 
basis of the relevant data, using equation 6 , the coefficients of the technical availability of a machine were calculated [35].

$$
\mathrm{A}=\frac{\mathrm{T}_{\mathrm{op}}}{\mathrm{T}_{\mathrm{op}}+\mathrm{T}_{\mathrm{ps}}+\mathrm{T}_{\mathrm{ns}}}
$$

\subsection{Survey Parameters}

The parameters which characterise the possible, current and previous work of the machine were complemented through the interview, with information based on the opinions of the people who were in daily contact with the machines. The survey questions were directed towards three groups of people: Surveillance technical staff (SS), maintenance staff (MS) and exploitation staff (ES). Each person in the three groups received eight questions in the survey which they were to answer using the grading system from 1 (the worst) to 10 (the best) to evaluate each of the different types of dozers (alternatives). It should be mentioned that the questions were adapted to each of the mentioned groups of surveyed people. The basis for defining the questions was the definition of the proper functioning of the dozer as well as raising the level of safety of the staff and the equipment [10].

After defining the structure of the AHP model (Figure 5), which is adapted for choosing the right type of dozer for certain conditions-achieved by defining adequate criteria and sub-criteria, as well as defining the choice alternatives - the conditions were met for applying the mathematical calculations with the purpose of finding the optimal solution.

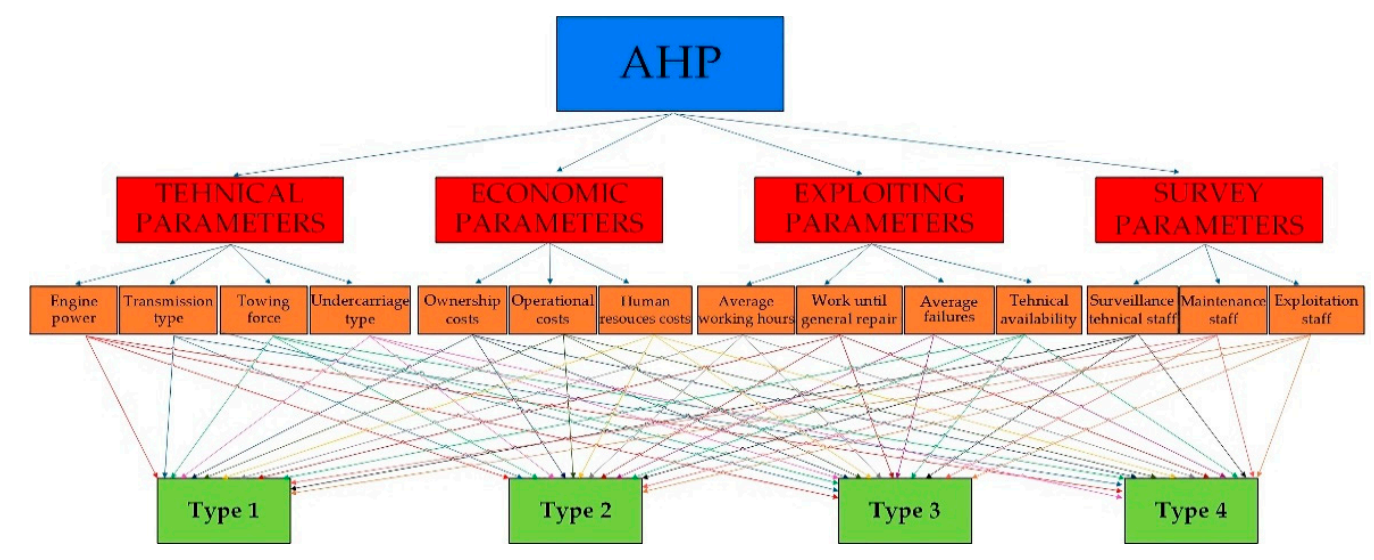

Figure 5. The structure of the model in choosing the dozers by applying the AHP method.

The first step was to define the basic criteria (technical, economic, exploitation, survey), using the coefficients of the same value $(0.250)$ the result of which was $1(100 \%)$ and sub-criteria. All the previously mentioned (input) data necessary for the analysis, results of the pair-wise comparison and ranking are presented in Tables 4-18. Because of the calculation complexity of the input data for analysis [33], only the final values of the considered alternatives are given in these Tables. Input data for the technical parameters are presented in Table 4.

Table 4. Input parameters for applying the AHP method for technical parameters.

\begin{tabular}{cccccc}
\hline \multirow{2}{*}{ Criteria } & \multirow{2}{*}{ Sub-Criteria } & \multicolumn{4}{c}{ Machines } \\
\cline { 3 - 6 } & & Type 1 & Type 2 & Type 3 & Type 4 \\
\hline \multirow{3}{*}{ Technical } & Engine power [kW] & 252 & 250 & 238 & 235 \\
parameters & Transmission type & Hydrodynamic & Hydrostatic & Hydrodynamic & Hydrodynamic \\
& Towing force [kN] & 315 & 292 & 302 & 317 \\
& Undercarriage type & Triangular & Flat & Flat & Flat \\
\hline
\end{tabular}


Table 5. Results of the pair-wise comparison of technical sub-criteria EP, TT, TF, UT.

\begin{tabular}{|c|c|c|c|c|c|c|c|c|c|c|c|}
\hline \multicolumn{6}{|c|}{ Engine Power (EP) } & \multicolumn{6}{|c|}{ Transmission Type (TT) } \\
\hline & T1 & T2 & T3 & $\mathrm{T} 4$ & Weight & & T1 & T2 & T3 & T4 & Weight \\
\hline $\mathrm{T} 1$ & 1 & 1 & 2 & 2 & 0.333 & T1 & 1 & $\frac{1}{2}$ & 1 & 1 & 0.200 \\
\hline $\mathrm{T} 2$ & 1 & 1 & 2 & 2 & 0.333 & $\mathrm{~T} 2$ & 2 & 1 & 2 & 2 & 0.400 \\
\hline T3 & $\frac{1}{2}$ & $\frac{1}{2}$ & 1 & 1 & 0.167 & T3 & 1 & $\frac{1}{2}$ & 1 & 1 & 0.200 \\
\hline $\mathrm{T} 4$ & $\frac{1}{2}$ & $\frac{1}{2}$ & 1 & 1 & 0.167 & $\mathrm{~T} 4$ & 1 & $\frac{1}{2}$ & 1 & 1 & 0.200 \\
\hline$\lambda_{\max }$ & & & 4 & & & $\lambda_{\max }$ & & & 4 & & \\
\hline CI & & & 0 & & & $\mathrm{CI}$ & & & 0 & & \\
\hline CR & & & 0 & & & CR & & & 0 & & \\
\hline \multicolumn{6}{|c|}{ Towing Force (TF) } & \multicolumn{6}{|c|}{ Undercarriage Type (UT) } \\
\hline & T1 & T2 & T3 & T4 & Weight & & T1 & T2 & T3 & T4 & Weight \\
\hline T1 & 1 & 3 & 2 & 1 & 0.351 & T1 & 1 & 2 & 2 & 2 & 0.400 \\
\hline $\mathrm{T} 2$ & $1 / 3$ & 1 & $\frac{1}{2}$ & $1 / 3$ & 0.109 & $\mathrm{~T} 2$ & $\frac{1}{2}$ & 1 & 1 & 1 & 0.200 \\
\hline T3 & $\frac{1}{2}$ & 2 & 1 & $\frac{1}{2}$ & 0.189 & T3 & $\frac{1}{2}$ & 1 & 1 & 1 & 0.200 \\
\hline $\mathrm{T} 4$ & 1 & 3 & 2 & 1 & 0.351 & $\mathrm{~T} 4$ & $\frac{1}{2}$ & 1 & 1 & 1 & 0.200 \\
\hline$\lambda_{\max }$ & & & 4.002 & & & $\lambda_{\max }$ & & & 4 & & \\
\hline CI & & & 0.000 & & & CI & & & 0 & & \\
\hline CR & & & 0.001 & & & CR & & & 0 & & \\
\hline
\end{tabular}

Table 6. Alternative ranking by technical parameters.

\begin{tabular}{ccc}
\hline Alternative & Weight Coefficient of Alternatives for Criteria TP & Rank \\
\hline T1 & $0.277 \cdot 0.333+0.095 \cdot 0.200+0.468 \cdot 0.351+0.160 \cdot 0.400=0.340=34 \%$ & 1 \\
T2 & $0.277 \cdot 0.333+0.095 \cdot 0.400+0.468 \cdot 0.109+0.160 \cdot 0.200=0.213=21.3 \%$ & 3 \\
T3 & $0.277 \cdot 0.167+0.095 \cdot 0.200+0.468 \cdot 0.189+0.160 \cdot 0.200=0.186=18.6 \%$ & 4 \\
T4 & $0.277 \cdot 0.167+0.095 \cdot 0.200+0.468 \cdot 0.351+0.160 \cdot 0.200=0.261=26.1 \%$ & 2 \\
\hline
\end{tabular}

Table 7. Input parameters for applying the AHP method for economic parameters.

\begin{tabular}{cccccc}
\hline \multirow{2}{*}{ Criteria } & \multirow{2}{*}{ Sub-Criteria } & \multicolumn{4}{c}{ Machines } \\
\cline { 3 - 5 } & & T1 & T2 & T3 & T4 \\
\hline \multirow{2}{*}{ Economic } & Ownership costs $[€ / \mathrm{mh}]$ & 15.51 & 17.73 & 11.77 & 9.92 \\
parameters & Operational costs $[€ / \mathrm{mh}]$ & 37.95 & 35.69 & 41.45 & 35.01 \\
& Human resource costs $[€ / \mathrm{mh}]$ & 11.79 & 11.79 & 11.79 & 11.79 \\
\hline
\end{tabular}

Table 8. Results of the pair-wise comparison of economic sub-criteria: Ownership costs (OW), operational costs (OP), and human resource costs (HR).

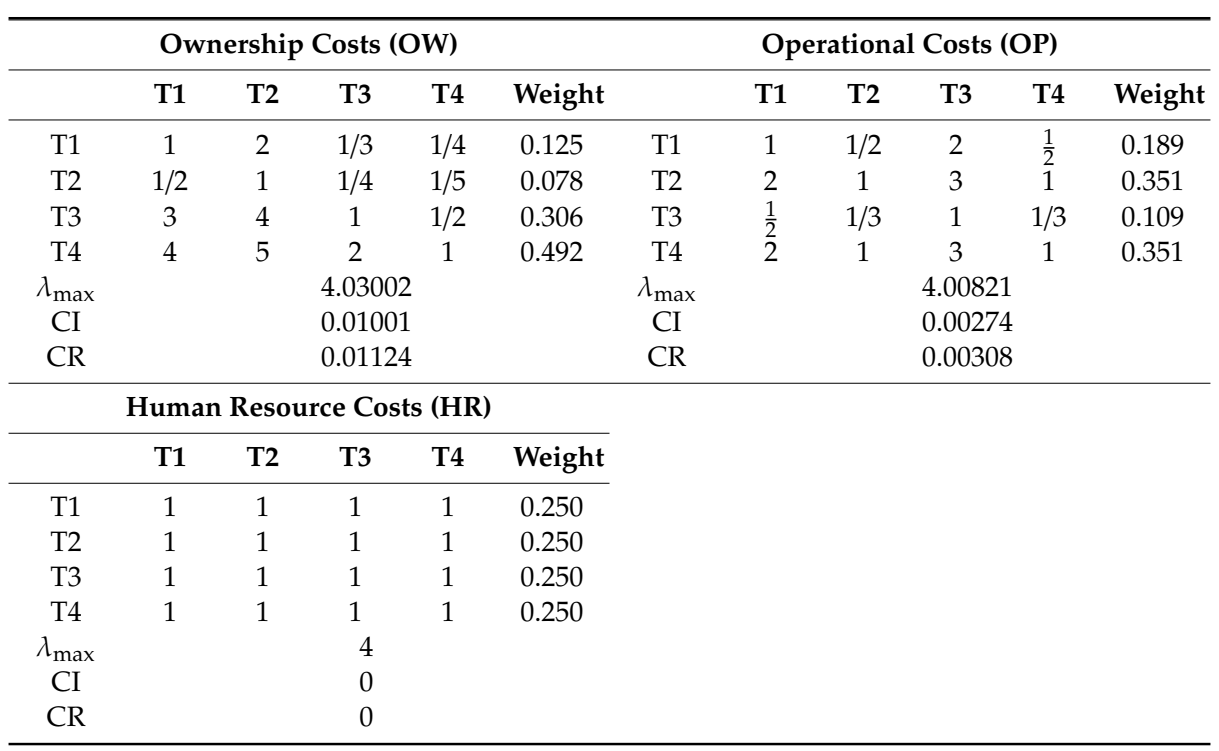


Table 9. Ranking by economic criteria.

\begin{tabular}{ccc}
\hline Alternative & $\begin{array}{c}\text { Weight Coefficient of } \\
\text { Alternatives for Criteria EcP }\end{array}$ & Rank \\
\hline \multirow{2}{*}{ T1 } & $0.297 \cdot 0.125+0.540 \cdot 0.189+$ & 4 \\
& $0.297 \cdot 0.250=0.180=18.0 \%$ & 2 \\
T2 & $0.163 \cdot 0.250=0.253=25.3 \%$ & 2 \\
& $0.297 \cdot 0.306+0.540 \cdot 0.109+$ & 3 \\
T3 & $0.163 \cdot 0.250=0.190=19.0 \%$ & \\
& $0.297 \cdot 0.492+0.540 \cdot 0.351+$ & 1 \\
T4 & $0.163 \cdot 0.250=0.377=37.7 \%$ & \\
\hline
\end{tabular}

Table 10. Input parameters for applying the AHP method for exploitation parameters.

\begin{tabular}{cccccc}
\hline \multirow{2}{*}{ Criteria } & \multirow{2}{*}{ Sub-Criteria } & \multicolumn{4}{c}{ Machines } \\
\cline { 3 - 6 } & & T1 & T2 & T3 & T4 \\
\hline \multirow{3}{*}{ Exploitation } & Working hours (mh/year) & 3127 & 2729 & 2639 & 3039 \\
parameters & General repair (mh) & 23638 & 18526 & 17389 & 19154 \\
& Average failures & 3.42 & 2.64 & 4.98 & 4.34 \\
& Technical availability & 0.89 & 0.89 & 0.81 & 0.81 \\
\hline
\end{tabular}

Table 11. Results of the pair-wise comparison of exploitation sub-criteria: Working hours $(\mathrm{WH})$, general repair (GR), average failures (AF), technical availability (TA).

\begin{tabular}{|c|c|c|c|c|c|c|c|c|c|c|c|}
\hline \multicolumn{6}{|c|}{ Working Hours (WH) } & \multicolumn{6}{|c|}{ General Repair (GR) } \\
\hline & T1 & T2 & T3 & $\mathrm{T} 4$ & Weight & & T1 & $\mathrm{T} 2$ & T3 & $\mathrm{T} 4$ & Weight \\
\hline $\mathrm{T} 1$ & 1 & 3 & 4 & 2 & 0.467 & $\mathrm{~T} 1$ & 1 & 3 & 4 & 3 & 0.516 \\
\hline $\mathrm{T} 2$ & $1 / 3$ & 1 & 2 & $1 / 2$ & 0.160 & $\mathrm{~T} 2$ & $1 / 3$ & 1 & 2 & 1 & 0.189 \\
\hline $\mathrm{T} 3$ & $\frac{1}{4}$ & $1 / 2$ & 1 & $1 / 3$ & 0.095 & $\mathrm{~T} 3$ & $\frac{1}{4}$ & $\frac{1}{2}$ & 1 & $\frac{1}{2}$ & 0.105 \\
\hline $\mathrm{T} 4$ & $\begin{array}{c}4 \\
1 / 2\end{array}$ & 2 & 3 & 1 & 0.277 & $\mathrm{~T} 4$ & $\begin{array}{c}4 \\
1 / 3\end{array}$ & 1 & 2 & 1 & 0.189 \\
\hline$\lambda_{\max }$ & \multicolumn{5}{|c|}{4.02322} & $\lambda_{\max }$ & \multicolumn{5}{|c|}{4.01268} \\
\hline CI & \multicolumn{5}{|c|}{0.00774} & $\mathrm{CI}$ & \multicolumn{5}{|c|}{0.00423} \\
\hline $\mathrm{CR}$ & \multicolumn{5}{|c|}{0.00869} & CR & \multicolumn{5}{|c|}{0.00475} \\
\hline \multicolumn{6}{|c|}{ Average Failures (AF) } & \multicolumn{6}{|c|}{ Technical Availability (TA) } \\
\hline & T1 & T2 & T3 & $\mathrm{T} 4$ & Weight & & T1 & $\mathrm{T} 2$ & T3 & $\mathrm{T} 4$ & Weight \\
\hline $\mathrm{T} 1$ & 1 & $\frac{1}{2}$ & 4 & 3 & 0.306 & $\mathrm{~T} 1$ & 1 & 1 & 4 & 4 & 0.400 \\
\hline $\mathrm{T} 2$ & 2 & 1 & 5 & 4 & 0.492 & $\mathrm{~T} 2$ & 1 & 1 & 4 & 4 & 0.400 \\
\hline $\mathrm{T} 3$ & $\frac{1}{4}$ & $1 / 5$ & 1 & $1 / 2$ & 0.078 & $\mathrm{~T} 3$ & $\frac{1}{4}$ & $1 / 4$ & 1 & 1 & 0.100 \\
\hline $\mathrm{T} 4$ & $\begin{array}{c}4 \\
1 / 3\end{array}$ & $1 / 4$ & 2 & 1 & 0.125 & $\mathrm{~T} 4$ & $\begin{array}{l}\frac{4}{1} \\
\frac{1}{4}\end{array}$ & $1 / 4$ & 1 & 1 & 0.100 \\
\hline$\lambda_{\max }$ & \multicolumn{5}{|c|}{4.03218} & $\lambda_{\max }$ & \multicolumn{5}{|c|}{4} \\
\hline CI & \multicolumn{5}{|c|}{0.01073} & CI & \multicolumn{5}{|c|}{0} \\
\hline $\mathrm{CR}$ & \multicolumn{5}{|c|}{0.01205} & $\mathrm{CR}$ & \multicolumn{5}{|c|}{0} \\
\hline
\end{tabular}

Table 12. Ranking by exploitation criteria.

\begin{tabular}{ccc}
\hline Alternative & Weight Coefficient of Alternatives for Criteria ExP & Rank \\
\hline T1 & $0.250 \cdot 0.467+0.250 \cdot 0.516+0.250 \cdot 0.306+0.250 \cdot 0.400=0.422=42.2 \%$ & 1 \\
T2 & $0.250 \cdot 0.160+0.250 \cdot 0.189+0.250 \cdot 0.492+0.250 \cdot 0.400=0.310=31.0 \%$ & 2 \\
T3 & $0.250 \cdot 0.095+0.250 \cdot 0.105+0.250 \cdot 0.078+0.250 \cdot 0.100=0.095=9.5 \%$ & 4 \\
T4 & $0.250 \cdot 0.277+0.250 \cdot 0.189+0.250 \cdot 0.125+0.250 \cdot 0.100=0.173=17.3 \%$ & 3 \\
\hline
\end{tabular}


Table 13. Input parameters for applying the AHP method for survey parameters.

\begin{tabular}{cccccc}
\hline \multirow{2}{*}{ Criteria } & \multirow{2}{*}{ Sub-Criteria } & \multicolumn{4}{c}{ Machines } \\
\cline { 3 - 5 } & & T1 & T2 & T3 & T4 \\
\hline \multirow{2}{*}{ Survey } & Surveillance technical staff & 7.95 & 6.40 & 5.38 & 2.05 \\
parameters & Maintenance staff & 8.60 & 6.63 & 7.18 & 5.83 \\
& Exploitation staff & 9.98 & 8.73 & 7.70 & 1.23 \\
\hline
\end{tabular}

Table 14. Results of the pair-wise comparison of survey sub-criteria: Surveillance technical staff (SS), maintenance staff (MS), exploitation staff (ES).

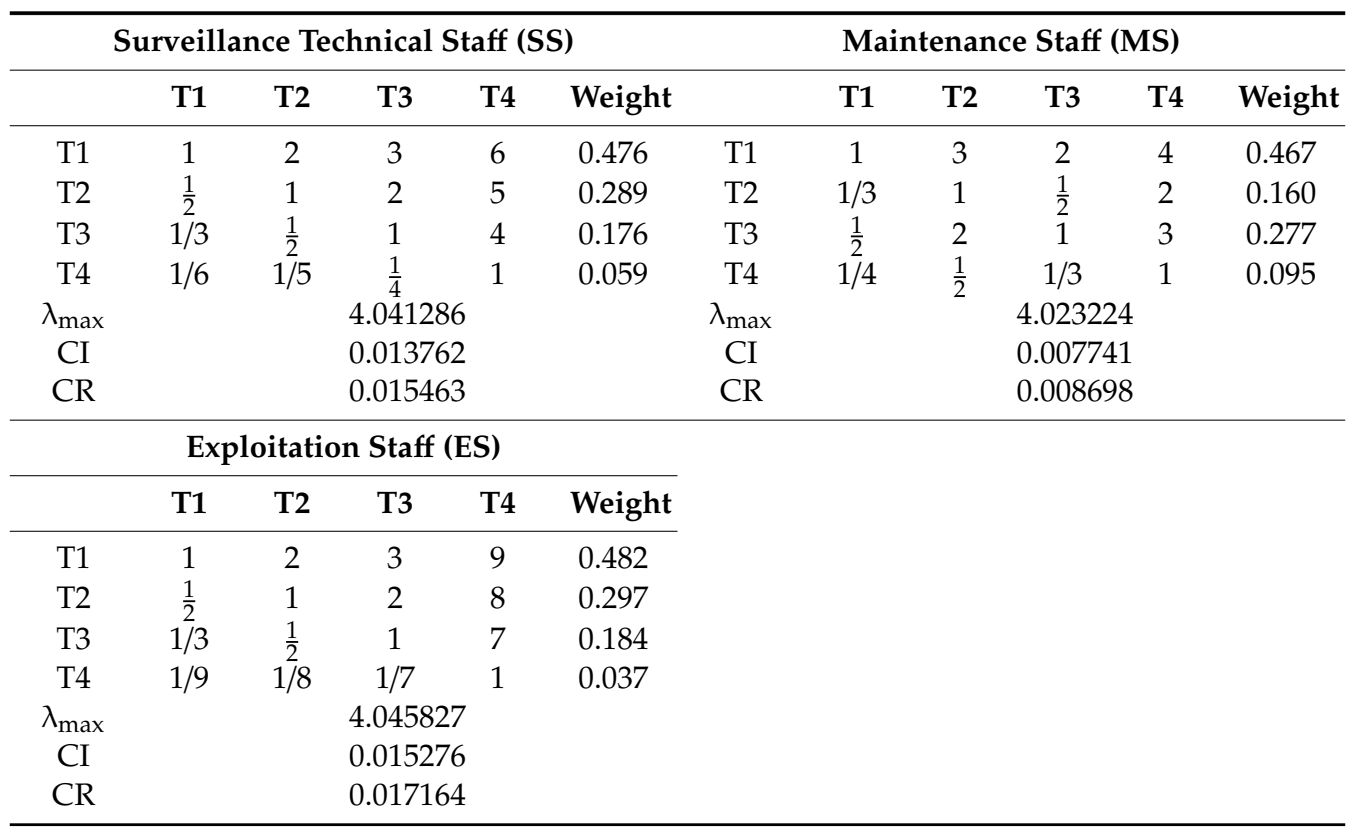

Table 15. Ranking by survey criteria.

\begin{tabular}{ccc}
\hline Alternative & $\begin{array}{c}\text { Weight Coefficient of } \\
\text { Alternatives for Criteria SP }\end{array}$ & Rank \\
\hline \multirow{2}{*}{ T1 } & $0.333 \cdot 0.476+0.333 \cdot 0.467+$ & \multirow{2}{*}{1} \\
& $0.333 \cdot 0.482=0.475=47.5 \%$ & 2 \\
T2 & $0.333 \cdot 0.289+0.333 \cdot 0.160+$ & 2 \\
& $0.333 \cdot 0.297=0.249=24.9 \%$ & 3 \\
T3 & $0.333 \cdot 0.176+0.333 \cdot 0.277+$ & \multirow{2}{*}{3} \\
& $0.333 \cdot 0.037=0.212=21.2 \%$ & 4 \\
T4 & $0.333 \cdot 0.059+0.333 \cdot 0.095+$ & \\
\end{tabular}

Table 16. Calculated weight coefficients by AHP analysis.

\begin{tabular}{cccccc}
\hline \multicolumn{2}{c}{ Weightiness of Sub-Criteria } & $\mathbf{0 . 2 5 0}$ & $\mathbf{0 . 2 5 0}$ & $\mathbf{0 . 2 5 0}$ & $\mathbf{0 . 2 5 0}$ \\
\hline \multirow{6}{*}{ Alternatives } & TP & EcP & ExP & SP \\
\hline & Weight coefficient of T1 & 0.340 & 0.180 & 0.422 & 0.475 \\
& Weight coefficient of T2 & 0.213 & 0.253 & 0.310 & 0.249 \\
& Weight coefficient of T3 & 0.186 & 0.190 & 0.095 & 0.212 \\
& Weight coefficient of T4 & 0.261 & 0.377 & 0.173 & 0.064 \\
\hline
\end{tabular}


Table 17. Alternative ranking.

\begin{tabular}{ccc}
\hline Alternative & Final Weight Coefficient of Alternatives & Rank \\
\hline T1 & $0.250 \cdot 0.340+0.250 \cdot 0.180+0.250 \cdot 0.422+0.250 \cdot 0.475=0.354=35.4 \%$ & 1 \\
T2 & $0.250 \cdot 0.213+0.250 \cdot 0.253+0.250 \cdot 0.310+0.250 \cdot 0.249=0.256=25.6 \%$ & 2 \\
T3 & $0.250 \cdot 0.186+0.250 \cdot 0.190+0.250 \cdot 0.095+0.250 \cdot 0.212=0.171=17.1 \%$ & 4 \\
T4 & $0.250 \cdot 0.261+0.250 \cdot 0.377+0.250 \cdot 0.173+0.250 \cdot 0.064=0.219=21.9 \%$ & 3 \\
\hline
\end{tabular}

Table 18. Final ranking of dozers by AHP.

\begin{tabular}{cc}
\hline Alternative & Rank \\
\hline T1 & 1 \\
T2 & 2 \\
T3 & 4 \\
T4 & 3 \\
\hline
\end{tabular}

In the following section, Sections 3.5-3.8, each sub-criterion is analysed separately, as well as the calculations for each alternative related to the mentioned sub-criteria.

\subsection{Results of Tehnical Parameters (TP)}

The most significant sub-criterion in the group of technical parameters is towing force, followed by engine power, type of undercarriage, and finally (as the least important parameter) the transmission type. Calculation of weight coefficients for the basic technical parameters is given as an example of AHP. The weight coefficients of the sub-criteria technical parameters were calculated with the mathematical matrix formed by comparing sub-criteria according to the defined preferences in Table 4 and by using the Saaty scale (Figure 3 and Table 2).

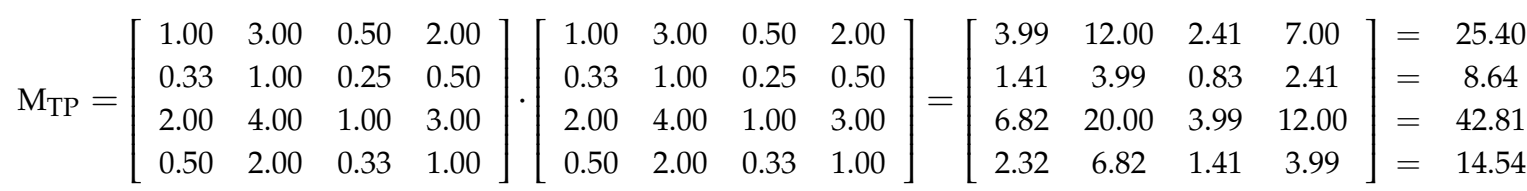

$$
\begin{aligned}
& \sum \mathrm{M}_{\mathrm{TP}}=25.40+8.64+42.81+14.54=91.39 \\
& \mathrm{~W}_{\mathrm{EP}}=\frac{25.40}{91.39}=0.277 \\
& \mathrm{~W}_{\mathrm{TT}}=\frac{8.64}{91.39}=0.095 \\
& \mathrm{~W}_{\mathrm{TF}}=\frac{42.81}{91.39}=0.468 \\
& \mathrm{~W}_{\mathrm{UT}}=\frac{14.54}{91.39}=0.160
\end{aligned}
$$

The next step was checking the consistency of the decision-maker by using Equations (3)-(5), where the condition was $\mathrm{CR}<0.1$,

$$
\begin{gathered}
\lambda_{\max }=3.83 \cdot 0.277+10.00 \cdot 0.095+2.08 \cdot 0.468+6.50 \cdot 0.160=4.02435 \\
C I=\frac{(4.02435-4)}{(4-1)}=0.008116 \\
C R=\frac{0.008116}{0.89}=0.009119
\end{gathered}
$$

The same principle was used in the interactions of evaluating alternatives according to the sub-criteria.

The results of this part of the analysis of technical criteria are shown in Table 5. 
To calculate the final value of technical parameters for each alternative it was necessary to apply Equation (7), which is used to normalize (weigh) the calculated values:

$$
\mathrm{TP}=\mathrm{TP}_{\mathrm{EP}} \cdot \mathrm{EP}_{\mathrm{n}}+\mathrm{TP}_{\mathrm{TT}} \cdot \mathrm{TT}_{\mathrm{n}}+\mathrm{TP}_{\mathrm{TF}} \cdot \mathrm{TF}_{\mathrm{n}}+\mathrm{TP}_{\mathrm{UT}} \cdot \mathrm{UT}_{\mathrm{n}}
$$

where $\mathrm{TP}_{\mathrm{EP}}, \mathrm{TP}_{\mathrm{TT}}, \mathrm{TP}_{\mathrm{TF}}, \mathrm{TP}_{\mathrm{TU}}$ are weight coefficients of sub-criteria engine power $(\mathrm{EP})$, transmission type (TT), towing force (TF) and undercarriage type (UT) in the group of technical parameters (TP), respectively, and $\mathrm{EP}_{\mathrm{n}}, \mathrm{TT}_{\mathrm{n}}, \mathrm{TF}_{\mathrm{n}}, \mathrm{UT}_{\mathrm{n}}$ are weight coefficients for $\mathrm{n}$ type of alternative according to sub-criteria engine power (EP), transmission type (TT), towing force (TF) and undercarriage type (UT), respectively. Result of alternative ranking according to technical parameters, are presented in Table 6.

The calculation of the remaining alternatives in this analysis was completed in the same way.

\subsection{Results of Economic Parameters $(E c P)$}

On the basis of the defined priorities among the sub-criteria of the economic parameters in Table 7, the following weight coefficients were calculated using the same principle that was used in calculating the technical parameters: OW (0.297); OP (0.540); HR (0.163).

Table 8 shows the pair-wise comparison of the alternatives according to economic sub-criteria.

For the final value of economic parameters for each alternative it was also necessary to apply a modified Equation (7). Results and alternative ranking are shown in Table 9.

\subsection{Results of Exploitation Parameters (ExP)}

Based on a comprehensive picture of the sub-criteria of the exploitation parameters Table 10, all of the sub-criteria were considered to be equally important for the successful functioning of the machine as well as its maintenance. It may be concluded that not a single sub-criterion could be prioritized as more important in relation to others which is why each criterion was assigned a weight coefficient of 0.250 .

The results of the calculated weight coefficients of alternatives from sub-criteria is shown in Table 11, while the final ranking according to the ExP criteria is in Table 12.

\subsection{Results of Survey Parameters (SP)}

The last criterion for forming the final evaluation were the survey parameters, which were analysed based on the answers to questions given by people who had been in daily contact with the dozers being considered. The survey was conducted in July 2018. As defined in Section 3.4, the surveyed people were grouped as SS, MS, and ES and for all of the mentioned sub-criteria an equal weight coefficient was adopted (0.333). Input data according to survey parameters are presented in Table 13.

The results of AHP analysis of survey sub-criteria are shown in Tables 14 and 15.

After defining and calculating all the weight priority vectors of the criteria and sub-criteria, the next step was to calculate each choice alternative. Table 16 contains all the necessary input parameters which were then implemented into the modified Equation (7), resulting in the end choice of the dozer.

The values of the results are shown respectively in Table 17.

\section{Discussion}

The application of the AHP method as one of the most used method of multicriteria decision analysis (MDCA) showed the rank of different types of dozer most commonly used auxiliary machine in open-cast coal mine of Kolubara. The subjects of the analysis were four dozers analysed by a combination of four basic criteria and 14 sub-criteria.

Based on the results, the most suitable type of dozer for the existent conditions was the Type 1 dozer, followed by the Type 2 dozer, the Type 4 dozer, and finally the Type 3 dozer as it is presented in Table 18. 
According to the technical parameters, the most suitable dozers were Type 1, followed by Type 4 , and then Types 2 and 3. The most economical dozer was Type 4, then Type 2, while Type 1 and 3 dozers were slightly more expensive. Type 1 and 2 dozers showed the best results given these specific conditions, and the same conclusion was confirmed by the expert opinion survey.

Even Type 4 had the best ranking according to economics parameters, exploitation parameters and expert opinion data proved that Type 1 and 2 dozers were used more in aggravated conditions and complex assignments. Aggravated circumstances cause an increase in operational costs, proving the importance of taking all parameters into consideration in an analysis.

To clearly illustrate the difference between the choice alternatives, a diagram showing the results according to dozer type is presented in Figure 6.

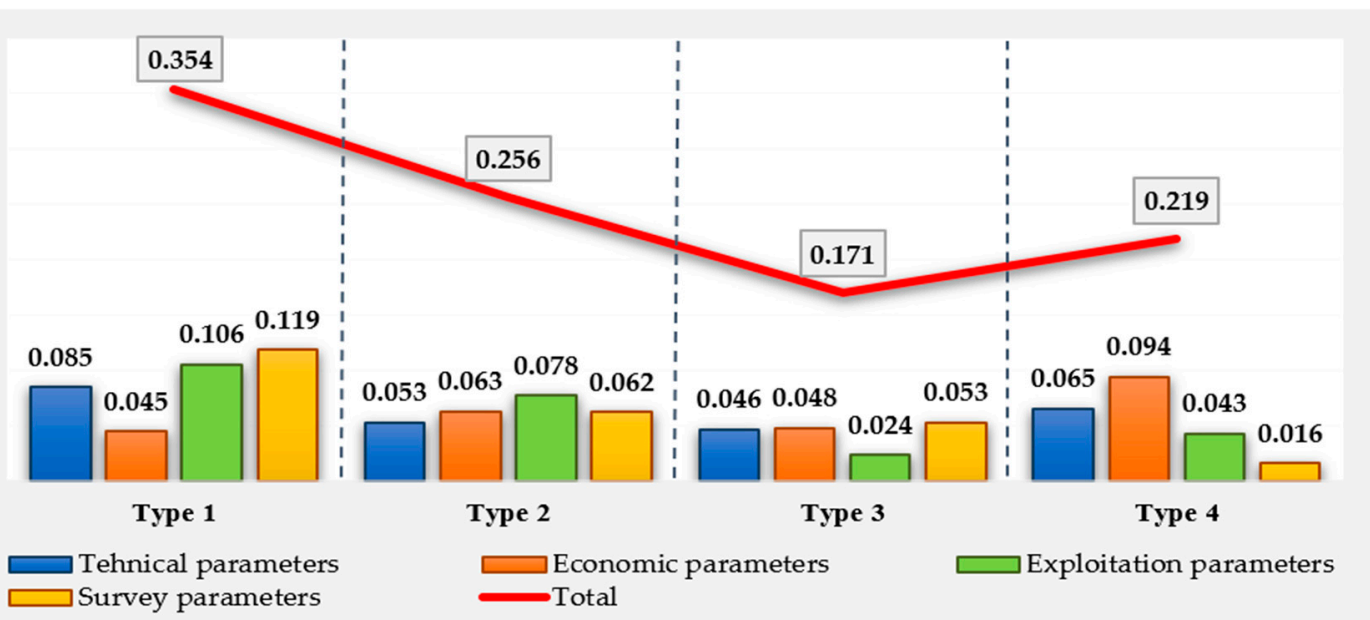

Figure 6. The structure of the model in choosing the dozer using the AHP method.

The diagram displays abscissa in different colors to show the priority coefficients of the basic parameters (technical, economic, exploitation, survey), grouped according to the dozer type. On the ordinate, the priority vectors are presented (scale range $0-0.40$ ). The red line shows the end collective results.

\section{Conclusions}

The choice of the optimal dozer type and manufacturer is a challenge influenced by multiple factors and criteria. It is necessary to consider all the parameters which influence dozer work in specific conditions when selecting new equipment. The advantages of selecting an adequate dozer are good performance, higher reliability, economic stability for the company, etc. A dozer that executes all its auxiliary work in a timely manner secures the health and safety of the employees and equipment. The costs don't consist solely of investing in new equipment. Considerable higher costs emerge with inadequate equipment selection, constant failures, inability to complete assignments and standstill.

To minimize the biased evaluation factor, this paper used the AHP method. The main purpose of the analysis is to define the "model itself" and after that comes the "finding of the optimal choice under the given circumstances". To prove the possibility of using the AHP method, we conducted an analysis of the evaluation of different parameters of the functioning of the dozer.

Taking into account that four basic criteria for decision-making were considered (technical, economic, exploitation and survey), the AHP method made it possible for those criteria to be weighed so that the final evaluation of the most suitable choice represented the result of all the considered parameters, even though their values could not be mutually compared and measured. This approach is transparent and easy to use and apply for the decision maker.

Determining the decision criteria and their preferences presents one of the major issues in the application of this method. Another issue with this method is the lack of objectivity in expert opinion. 
The AHP method, in addition to the results represented in the paper, provides the conditions for a partial analysis of each criterion, which are analysed in a very simple way. In that way the method can be adapted to the conditions in a given open-cast coal mine. By making the changes in the weight coefficients of the basic parameters, an analysis of the susceptibility to a desired criterion is possible, which is an additional advantage of applying the AHP method.

Author Contributions: Conceptualization, I.R. and D.I.; methodology, T.S. and S.D.; validation, P.J.; formal analysis and writing - original draft preparation, I.J.

Funding: This research and the APC was funded by the Ministry of Education and Science of the Republic of Serbia within the framework of Programme of research in the field of technological development projects TR 33039 and TR 33025.

Acknowledgments: This paper was realized as a part of the project "Improvement of Lignite Opencast Technology in Order to Increase Energy Efficiency and Occupational Safety" (TR 33039) and a part of the project "Research on possibility for AT (Advanced Technology) rockbolting application in mines for the purpose of increasing work safety and production efficiency" (TR 33025), financed by the Ministry of Education and Science of the Republic of Serbia within the framework of Programme of research in the field of technological development for the period 2011-2019.

Conflicts of Interest: The authors declare no conflict of interest.

\section{References}

1. Billings, R.; Scherer, L. The Effects of response mode and importance on decision-making strategies: Judgment versus choice. Organ. Behav. Hum. Decis. Process. 1998, 41, 1-19. [CrossRef]

2. Keen, P. Decision support systems: The next decade. Decis. Support Syst. 1987, 3, 253-265. [CrossRef]

3. Saaty, T.L.; Vargas, L.G. Models, Methods, Concepts \& Applications of the Analytic Hierarchy Process; Springer Science \& Business Media: New York, NY, USA, 2012; Volume 175.

4. Mohamadibadi, H.S.; Tichkowsky, G.; Kumar, A. Development of a Multi-Criteria Assessment Model for Ranking of Renewable and Non-Renewable Transportation Fuel Vehicles. Energy 2009, 34, 112-125. [CrossRef]

5. Govindan, K.; Jepsen, M.B. ELECTRE: A compehensive literature review on methodologies and applications. Eur. J. Oper. Res. 2016, 250, 1-29. [CrossRef]

6. Tsaur, R.C. Decision risk analysis for an interval TOPSIS method. Appl. Math. Comput. 2011, 218, 4295-4304. [CrossRef]

7. Gutiérrez, L.; Muñoz-Carpintero, D.; Valencia, F.; Sáez, D. A new method for identification of fuzzy models with controllability constraints. Appl. Soft Comput. 2018, 73, 254-262. [CrossRef]

8. Tavana, M.; Di Caprio, D.; Santos-Alteaga, F. An extended stochastic VIKOR model with decision maker's attitude towards risk. Inf. Sci. 2018, 432, 301-318. [CrossRef]

9. Đenadić, S.; Miletić, F.; Kovač, A.; Ivanović, J. Metodologija ocenjivanja parametara dozerske mehanizacije u RB Kolubara. In VI Savetovanje sa Međunarodnim Učešćem Energetika i Rudarstvo; Privredna Komora Srbije: Beograd, Serbia, 2018; pp. 274-283. ISBN 978-86-80420-16-5.

10. Đenadić, S.; Miletić, F.; Jovančić, P.; Janković, I.; Lazić, M. Analitičko hijerarhijski proces primenjen za selekciju hidrauličnih bagera na površinskim kopovima. In Proceedings of the VIII Međunarodna Konferencija OMC 2018, Zlatibor, Serbia, 17-20 Ocotober 2018; Jugoslovenski Komitet za Površinsku Eksploataciju: Belgrade, Serbia, 2018; pp. 14-22, ISBN 978-86-83497-25-6.

11. Ristovic, I.; Ignjatovic, D. The Reliability of Dozers on the Open Pits of Lignite in Serbia. In Proceedings of the International Carpathian Control Conference, Podbanske, Slovakia, 23-26 May 2000; pp. 153-158, ISBN 80-7099-510-6.

12. Ignjatovic, D.; Ristovic, I.; Stojakovic, M. The Methodology of the Selection of Auxiliary Mechanisation for the Open Pit Mines of Llignite. In Proceedings of the Mine Planning and Equipment Selection, Athens, Greece, 6-9 November 2000; pp. 577-581.

13. Nichols, H.; Day, D. Moving the Earth: The Workbook of Excavation; McGraw-Hill Professional: New York, NY, USA, 1998; pp. 15.27-15.43.

14. Ignjatović, D. Mašine i Pomoćni Radovi na Površinskim Kopovima; Rudarsko-Geološki Fakultet: Beograd, Serbia, 2017; pp. 60-62. 
15. Ignjatović, D. Rudarske Mašine; Rudarsko-Geološki Fakultet: Beograd, Serbia, 2013; pp. 285-290.

16. Saaty, T.L. Decision Making: The Analytical Hierarchy Process; Mc-Graw-Hill: New York, NY, USA, 1980.

17. Maruthur, N.M.; Joy, S.M.; Dolan, G.J.; Shihab, M.H.; Singh, S. Use of the Analytic Hierarchy Process forMedication Decision-Making in Type 2 Diabetes. PLoS ONE 2015, 10, e0126625. [CrossRef]

18. Veisi, H.; Liaghati, H.; Alipour, A. Developing an ethics-based approach to indicators of sustainable agriculture using analytic hierarchy process (AHP). Ecol. Indic. 2016, 60, 644-654. [CrossRef]

19. Ecer, F. A hybrid banking websites quality evaluation model using AHP and COPRAS-G: A Turkey case. Technol. Econ. Dev. Econ. 2014, 20, 758-782. [CrossRef]

20. Mohammed, S.M.Z.; Mohd, A.R.; Singh, M.M. A Secure Mobile App Solution Using Human Behavioral Context and Analytic Hierarchy Process. Procedia Comput. Sci. 2015, 72, 434-445. [CrossRef]

21. Kolak, I.O.; Feyzioglu, O.; Noyan, N. Bi-level multi-objective traffic network optimisation with sustainability perspective. Expert Syst. Appl. 2018, 104, 294-306. [CrossRef]

22. Sitorus, F.; Ciliers, J.J.; Brito-Parada, P.R. Multi-criteria decision making for the choice problem in mining and mineral processing: Applications and trends. Expert Syst. Appl. 2018, 121, 393-417. [CrossRef]

23. Shen, L.; Muduli, K.; Brave, A. Developing a sustainable development framework in the context of mining industies: AHP approach. Resour. Policy 2013, 46, 15-26. [CrossRef]

24. Milisavljević, V.; Medenica, D.; Čokorilo, V.; Ristović, I. New approach to equipment quality evaluation method with distinct functions. Termal. Sci. 2016, 20, 743-752. [CrossRef]

25. Stevanović, D.; Lekić, M.; Kržanović, D.; Ristović, I. Application of MCDA in selection of different mining methods and solutions. Res. J. 2018, 12, 171-180. [CrossRef]

26. Milentijevíc, G.; Nedeljkovíc, B.; Lekíc, M.; Nikíc, Z.; Ristovíc, I.; Djokíc, J. Application of a Method for Intelligent Multi-Criteria Analysis of the Environmental Impact of Tailing Ponds in Northern Kosovo and Metohija. Energies 2016, 9, 935. [CrossRef]

27. Malenovic-Nikolic, J.; Vasovic, D.; Filipovic, I.; Musicki, S.; Ristovic, I. Application of Project Management Process on Environmental Management System Improvement in Mining-Energy Complexes. Energies 2016, 9 , 1071. [CrossRef]

28. Karimnia, H.; Bagloo, H. Optimum mining method selection using fuzzy analytical hierarchy process-Qapiliq salt mine, Iran. Int. J. Min. Sci. Technol. 2015, 25, 225-230. [CrossRef]

29. Saaty, T.L. Decision making with the analytical hierarchy process. Int. J. Serv. Sci. 2008, 1, 83-98.

30. Aleksi, I.; Hocenski, Z. Primjena Expert-Choice Alata i AHP Metode za Odabir Virtex-5 FPGA Čipa; Elektrotehnički fakultet sveučilišta: Osijek, Croatia, 2009.

31. Jamshidi, M.; Ataei, M.; Sereshki, F.; Jalali, S.M.E. The application of AHP approach to select of optimum underground mining method, case study: JAJAM Bauxite mine (IRAN). Arch. Min. Sci. 2009, 54, 103-117.

32. Kelić, N.V. Hidroprenosnici; Naučna Knjiga Beograd: Beograd, Serbia, 1989.

33. Optimizacija organizacije sredstava i troškova pomoćne mehanizacije u cilju povećanja stepena iskorišćenja jalovinskih i ugljenih sistema na površinskim kopovima EPS-a; Rudarsko-Geološki Fakultet: Beograd, Serbia, 2018.

34. Jovančić, P. Održavanje Rudarskih Mašina; Rudarsko-Geološki Fakultet: Beograd, Serbia, 2014; pp. $22-25$.

35. Ignjatović, D.; Jovančić, P.; Janković, I.; Đenadić, S.; Miletić, F. Analiza trenda tehničke raspoloživosti buldozera na površinskim kopovima Elektroprivrede Srbije. In Proceedings of the VII Međunarodna konferencija Ugalj, Zlatibor, Serbia, 11-14 October 2017; Jugoslovenski Komitet za Površinsku Eksploataciju: Belgrade, Serbia, 2017; pp. 101-110, ISBN 978-86-83497-24-9.

(C) 2019 by the authors. Licensee MDPI, Basel, Switzerland. This article is an open access article distributed under the terms and conditions of the Creative Commons Attribution (CC BY) license (http://creativecommons.org/licenses/by/4.0/). 